RACIST LOVE

迠 


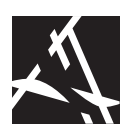

ANIm A Critical Race Studies Otherwise A series edited by Mel Y. Chen and Jasbir K. Puar

Duke University Press Durham and London 2022 


\title{
RACIST LOVE
}

ASIAN ABSTRACTION AND

THE PLEASURES OF FANTASY

\author{
Leslie Bow
}


(C) 2022 Duke University Press

All rights reserved

Printed in the United States of America on acid-free paper $\infty$

Cover designed by A. Mattson Gallagher

Text designed by Courtney Leigh Richardson

Typeset in Knockout and Garamond Premier Pro

by Westchester Publishing Services

Library of Congress Cataloging-in-Publication Data

Names: Bow, Leslie, [date] author.

Title: Racist love : Asian abstraction and the pleasures of fantasy /

Leslie Bow.

Other titles: ANim A (Duke University Press)

Description: Durham : Duke University Press, 2022.| Series: Anima:

critical race studies otherwise | Includes bibliographical references

and index.

Identifiers: LCCN 2021022580 (print)

LCCN 202102258I (ebook)

IS BN 9781478015222 (hardcover)

IS BN 978147801785 I (paperback)

ISBN 9781478022466 (ebook)

Subjects: LCSH: Asian Americans-Public opinion. | Asian Americans-Social conditions. | Asian Americans-Ethnic identity. | Racism-United States. | United States-Race relations. | BIS AC: Social science / Ethnic Studies / American / Asian American Studies

Classification: LCC E I84.A75 G 742022 (print)|

LCC E I84.A75 (ebook) | D DC 305.895/073-dc23

LC record available at https://lccn.loc.gov/2021022580

LC ebook record available at https://lccn.loc.gov/202102258I

Cover art: Hong Chun Zhang, Three Graces (right detail), 20 II.

Charcoal on paper with scrolls; triptych, left and right: $36 \times 96 \mathrm{in}$., center: $36 \times$ Ioo in. Photographed by Aaron Paden. Courtesy of the artist. 
IN LOVING MEMORY OF

WILLIE BOW

1931-2017

AND

SUE MAE BOW

1936-2021 


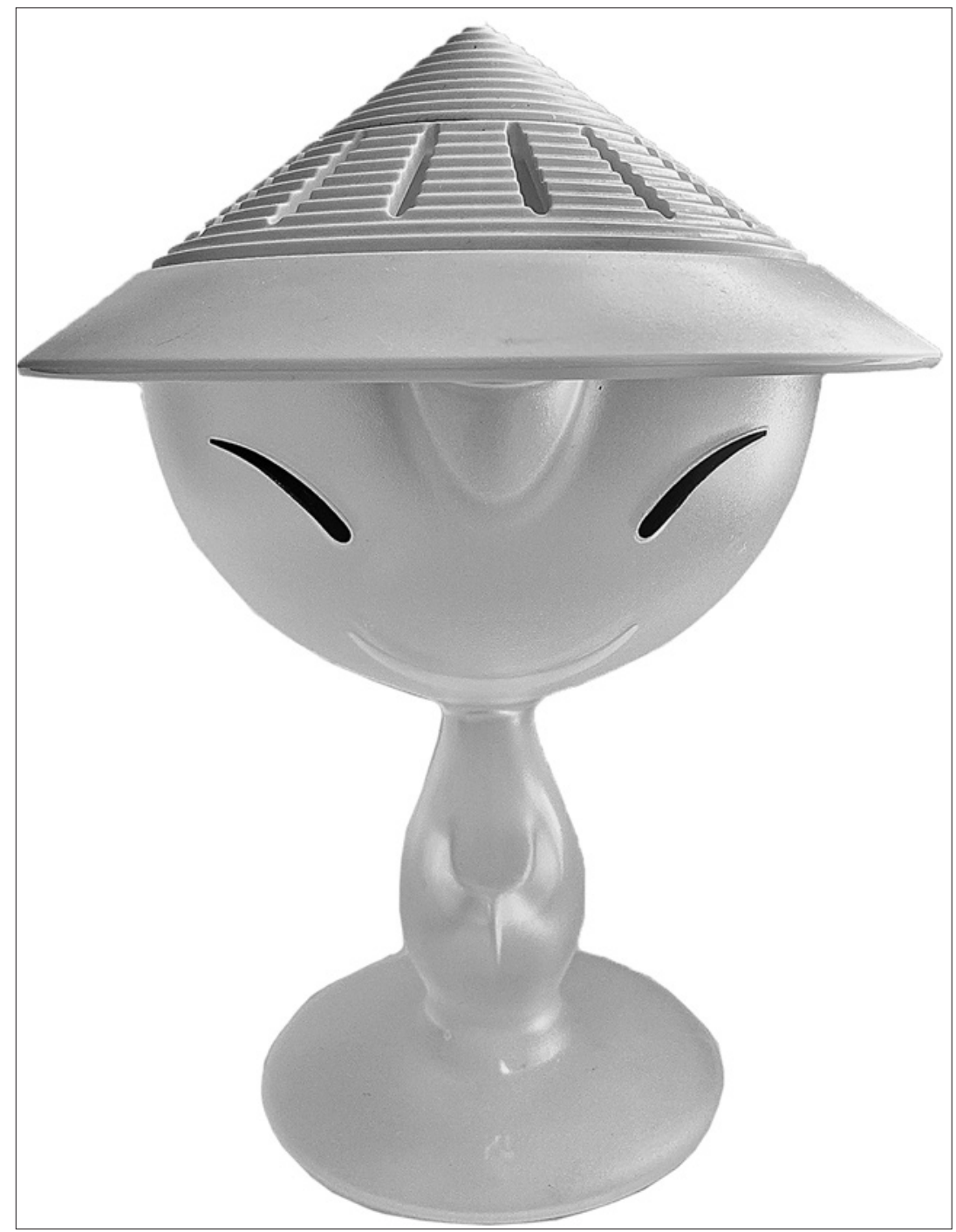

